\title{
The Need for Audit Trinity Report to Reinforce
}

\section{Financial Reporting Integrity}

\author{
Mohammad K. Shbeilat ${ }^{1}$ \\ ${ }^{1}$ Faculty of Business, Tafila Technical University, P. O. Box 179, Tafila 66110, Jordan \\ Correspondence: Mohammad K. Shbeilat, Faculty of Business, Tafila Technical University, P. O. Box 179, Tafila \\ 66110, Jordan. E-mail: shbeilat@ttu.edu.jo, shbeilat@yahoo.com
}

Received: October 21, 2018

Accepted: November 21, $2018 \quad$ Online Published: November 22, 2018

doi:10.5430/afr.v7n4p184

URL: https://doi.org/10.5430/afr.v7n4p184

\begin{abstract}
Investors' reliability on financial statements decreases due to continuing corporate scandals. Many of these rogue listed companies have had dominant shareholders who have circumvented internal controls for personal gain or have hidden poor management using misleading reporting. This has led to calls for restructuring the annual financial report and to fill the gap of corporate governance constituents. This study aims to highlight the importance of combining the efforts of the audit trinity (those are: the audit committee, the external auditor and the internal auditor) in securing the financial reporting system and corporate governance. This literature-based study suggests coordinating and integrating the efforts of the audit trinity and the issue a joint report addressing all matters related to (1) safeguarding company's assets and accounts (2) ensuring that financial statements and the annual report are fair, balanced and reliable, and (3) ensure the entity's compliance with applicable laws, corporate governance code, and accounting and auditing standards. The proposed joint report is to be signed by the audit trinity and certified by the chairperson of the board. The development of this report went through two stages, the first one, reviewing related literature, internationally recognized frameworks and corporate governance best practices, and related international standards on auditing; the second stage was sending the draft of the proposed report to 20 expert referees requesting their comments on the structure and the appropriateness of the proposed report. The proposed report helps by clarifying the communication mechanism, responsibilities and powers of the audit trinity that enable them to adequately discharge their duty of maintaining corporate accountability and securing the financial reporting system. It also addressed the need to have informed and stringent control over the quality of financial reporting and avoidance of conflicts of interest.
\end{abstract}

Keywords: reliability of financial statement, corporate governance, audit committees, external auditor, internal auditors, audit trinity, joint report, annual financial report

\section{Introduction}

Can external auditors be trusted?. "Are we going to see an even more draconian Sarbanes Oxley version 2?". These questions were raised by Cooper \& Grose (2010, p. 163) after reviewing corporate collapses during and before the Global Financial Crisis (GFC). They also noted that corporate scandals such as the implosion of Enron and Arthur Andersen in the U.S.A, Satyam in India, and Chuo-Aoyama PricewaterhouseCoopers in Japan had negatively impacted the auditing profession. Many of these rogue listed companies have had dominant shareholders who have circumvented internal controls for personal gain or have hidden poor management using misleading reporting (Nawawi \& Salin, 2018; Dibra, 2016; Yeoh, 2015). Indeed, continual management misconduct, CPA's quality control violations and failure (see for example: PCAOB, 2018a; 2018b; Sweet, 2018; Mak, et al. 2005) and the recent suspension of KPMG from auditing Omani companies for a one year due to failure of discovering major financial and accounting irregularities (Jr, 2018) send us warning signals that corporate governance system and the role of the tripartite auditors (i.e. audit committee, external auditor, and internal auditor) need to be restructured to have extra tools of securing the financial reporting system and corporate accountability.

Reforming corporate governance systems does not mean establishing more committees without sufficient power, or by adopting modern corporate governance instructions of developed countries with superficial implementation (Al-Baidhani, 2014). The traditional standard annual corporate report needs to be restructured to provide a higher level of transparent and reliable information (Al-Sawalqa, 2013). Listed companies also need to establish effective 
committees to ensure that accountability is applied at all administrative levels and to reinforce corporate integrity and values.

One of the most important corporate governance pillars is the audit committee since it has formidable responsibilities in securing the financial reporting system (Shbeilat, 2014). Audit committees responsibilities of securing the soundness of financial statements stem from their power of nominating, supervising and coordinating the work of both internal and external auditors. The "audit trinity" or the "tripartite audit function", which comprises of audit committees, external and internal auditors, have a major role in securing sufficient discharge of corporate accountability (Porter, 2008; 2009). Principles of corporate governance are greatly strengthened when the audit trinity collaborates in their roles in an effective manner. In describing their vital roles, Boţa-Avram (2011) pointed out that the audit trinity "players" have significant and interacting joint roles in corporate governance. For this reason, most of the worldwide corporate governance codes pay greater attention to clarify their roles and duties in order to combat financial and administrative corruption.

This paper suggests that the audit trinity must work under a pre-approved charter, coordinate their efforts, and to include the result of their work as a separate joint report within the company's annual report. The proposed joint report addresses the importance of forming independent, qualified and effective audit committees to be positively reflected in their roles of nominating, remunerating, retaining, communicating and coordinating duties of both external and internal auditors. It also addressed the need to have informed and stringent control over the quality of financial reporting and avoidance of conflicts of interest.

\section{Contributions \& Objectives of the Study}

Successive events of corporate corruption and firm scandals led to calls for restructuring the standard financial reporting, fill the gap of corporate governance constituents to effectively secure corporate accountability and establishing a new regulatory framework and legislation for external auditors (Rezaee, 2005; Al-Sawalqa, 2013). The proposed audit trinity report of this study provides guidance and insights of coordinating the roles of tripartite audit-governance tools which is ultimately reflected in the fairness, transparency, integrity and the credibility of financial statements. Moreover, while the U.S. Sarbanes Oxley act added more responsibilities to the CEO and CFO if there are misstatements in the financial statements, the proposed audit trinity report of this study suggests more responsibilities to the tripartite audit of the company by signing the report as evidence of carrying out their stipulated roles and responsibilities. Furthermore, it is worth mentioning that the Guidance on Audit Committees issued by The UK Financial Reporting Council requires audit committees to include a separate section in the annual report describing their work. However, the proposed audit trinity report of this study is more comprehensive in that it includes a joint report integrating the efforts of the audit committee, external auditor, and internal auditor.

The objectives of the proposed audit trinity report can be summarized as follow:

1- Improve financial reporting disclosure and transparency in listed companies' annual reports.

2- Enhancing corporate accountability of directors, management, and auditors as the addition of the signed audit trinity report to the annual report means that they certify they have adequately discharged their responsibility of securing the internal control system and financial statements.

3- Directing regulators to the importance of integrating the roles of audit committees, external auditors, and internal auditors in securing the financial reporting system and in reinforcing the entity's compliance with legislation in force and adopted corporate governance codes.

4- Introducing a new model of audit trinity report to strengthen the pillars of corporate governance by providing an extra layer of assurance to shareholders and financial community.

\section{Method}

The methodology employed in developing the audit trinity report of this study passed through two phases. Firstly: examination of relevant literature to explore the need to develop an additional element of securing corporate accountability and the financial reporting system. This includes surveying research papers and articles, conference papers on corporate governance, bulletins of capital market regulating bodies in developed countries (such as the PCAOB and SOX of the USA, the FRC of the UK, the Australian ASX using Corporate Governance Principles), International Standards on Auditing (ISAs) especially those related to corporate governance and to the relation between audit committees with external and internal auditors.

Secondly, the first draft of the model was sent to 20 expert referees. They were asked to comment on the appropriateness of the model in securing corporate accountability and the reliability of financial statements. They 
also were requested to provide any suggestions and feedback to enhance and enrich the proposed audit trinity report. The draft was delivered by hand to 5 university lecturers in accounting and auditing, five external auditors, five audit committee members and five internal auditors of listed companies at the Amman Stock Exchange in Jordan. Valuable feedback and suggestions were received from all the referees and had been considered in the final version of the report model. Examples of their recommendations (1) the inclusion of a table of Non-Audit Services (NAS) performed by external auditors showing the percentage of (NAS) fees to total fees paid to external auditors (2) the necessity to certify the report also by the chairperson of the board of director beside the audit trinity, because, legally, the board of directors have the ultimate responsibility before the securities commission.

\section{Theoretical Framework \& Literature Review}

In some of the early corporations, both stockholders and company managers used to audit a company's financial records and statements, (Watts \& Zimmerman, 1983). The core concept of the agency theory revolves around the separation of ownership from management. Agency costs arise when the goals of the principal differ from the ones of the agent (Boţa-Avram, 2011) with the possibility that managers may opportunistically prioritize their self-interests at the expense of company owners (Jensen \& Meckling, 1976). So, "agency theory is grounded in a rather pessimistic view of human motivation" (Tillema \& ter Bogtt, 2016, p. 137). The use of an independent auditor began in the second half of the nineteenth century (Watts \& Zimmerman, 1983). From that time, an inherent conflict of interests exists for external auditors, because they audit financial statements prepared by the company management and receive their fees from them (Gavious, 2007). The fear is when auditors "become subject to the principal's control and cannot act independently" (Bratton, 2003 p. 444) due to incentives to retain the economic relationship with the company.

However, the role of external auditors in protecting the company's assets and overseeing management activities is appreciated by the community to mitigate agency problem (Jensen and Meckling, 1976). Fan \& Wong (2005) surveyed East Asia markets to investigate whether external auditors play a role in mitigating agency problem in terms of concentrated ownership, the study indicated that in companies subject to greater agency problems, the owners, especially the controlling owners, prefer to elect Big 5 auditors to mitigate agency problems and to protect the rights of the minority owners.

The internal audit function, the third governing tool has the potential as important a role as external auditors in securing the company's financial statements (Oussii \& Boulila Taktak, 2018; Janvrin, 2008; Endaya \& Hanefah, 2016). Although historically, the internal audit function is regarded as a non-independent activity (unlike external auditors), the Institute of Internal Auditors (IIA) starts defining Internal audit as an independent activity (IIA, 2017). However, the issue of the independence of the internal auditor has proponents who affirm that enhancing internal audit independence could be achieved if they work under a direct authority of a fully independent audit committee. Internal auditors who are backed, supported and appointed by the independent audit committee, have greater power to report irregularities without fear of pressures from executives (Roussy \& Brivot 2016; Alqatamin, 2018; Stewart \& Subramaniam, 2010; Christopher et al., 2009; Prawitt et al., 2009). Roussy \& Brivot (2016) pointed out that the higher the audit committee independence, the greater the independence and effectiveness of the internal auditors. They further added that to limit the executive's influence on internal audit function, internal audit procedures and budgets should not be determined by the company management, they must be monitored by the audit committee.

According to the EU Company Law Directive, a powerful audit committee plays a significant role in securing corporate reporting through the following three main dimensions: 1) overseeing the financial reporting process 2) monitoring the work of internal auditors, and 3) monitoring the work performance and independence of external auditors (Bajra \& Cadez, 2018). In the Korean market, Choi et al., (2014) confirmed that strong audit committees in terms of independence and financial literacy strengthen corporate governance systems, maximise shareholders' wealth, and mitigate self-interested and opportunistic management behaviour. A similar study in Korea conducted by Park (2018) concluded that a well-established audit committee working under effective charter ensure higher quality audit practices and mitigates management influence on auditor's selection. In the same context, but in the U.S.A, Beck \& Mauldin (2014) noted executives' influence on audit fees even though theoretically and legally audit committees are charged with the responsibility of discussing audit fees. They conducted a study to answer the question of who's really in charge of negotiating audit fees, Audit Committees or CFOs?. The study concluded that a powerful audit committee limits the CFO's intervention in the audit fee especially during recessionary periods which require auditors to provide higher assurance and therefore, higher audit fees.

The potential and actual conflicts of interests resulting from providing non-audit services to the audit client are still hotly debated between academicians and practitioners. Many academicians argue that the link between providing a 
higher proportion of non-audit services and the possibility of a conflict of interests facing external auditors, thereby impairing their actual or perceived independence (Gavious, 2007; Krishnan, et al., 2005; Schneider, et al., 2006; Law, 2008). On the other hand, practitioners, especially the Big Four, are still defending the provision of non-audit services and "are adamant that investor concerns over their non-audit earnings from [their] audit clients are completely unwarranted" (Nixon, 2004, p. 34). In line with practitioners' arguments, other studies found no negative relationship between non-audit services and audit performance especially when the company monitors the provision of NAS (Craswell et al., 2002; Al-Hajri 2018; Sharma \& Sidhu 2001; McMillan 2004; Zhang et al., 2016; Wang \& Hay 2013). Therefore, disclosing pre-approved non-audit services by the company audit committees implies two valuable messages to owners, the first one is the positive side of disseminating clear, detailed, and transparent information regarding both audit and non-audit services, the second message conveyed is that certifying members of the audit committee declare they have reviewed and scrutinised non-audit services before giving approval, and thus they provide reassuring message that there is no conflict of interest due to performing non-audit services.

As a conclusion, modern corporate governance best practices deal with agency problems by finding a suitable mechanism for the relationship between the company management and both external and internal auditors on the one hand, and between the company management with directors and owners on the other hand. An important solution to mitigate the agency problem starts by having an independent audit committee to monitor all communications between the company management and auditors in relation to the appropriateness of the application of both accounting and auditing standards (Shbeilat \& Harasis 2018). These solutions featured by vesting the power of nominating, remunerating, retaining and formally communicating with external auditors to that independent committee, not the company management. Similarly, in an attempt to mitigate agency problem, internal auditors' independence and effectiveness are reinforced by having the internal auditors report directly to the board of directors and "have access to and ongoing communications with the audit committee" (Arens et al., 2017. p. 875). Such effective relationship among tripartite audit aims at providing a monitoring device which can help the company in protecting the interests of the owners by curbing the opportunistic behaviour of the company management.

\section{The Dynamic Audit Trinity Reporting Model}

Figure one shows that the preparation of financial statements in accordance with the International Financial Reporting Standards (IFRS) rests with the company management. While the role of the external auditor is to audit financial statements based on international standards on auditing and to express an opinion about their fairness in accordance with local laws and international accounting, the internal auditors also check the accuracy of accounting records and financial reports according to the applicable internal control framework (e.g. COSO, IIA). The figure also highlights the vital role of the audit committee as a liaison between external and internal auditors. Audit committees communication with external auditors include discussing all decisions related to the external auditor (e.g. selection, removal, remuneration, the extension of the scope of the audit beyond that required by applicable laws and regulations, and terms of the audit engagement, approving non-audit services and the engagement letter). Similarly, the audit committee communications with internal auditors also means discussing all major decisions related to the internal auditors including the appointment of the chief internal auditors. The figure also reveals the role of the audit committee in approving financial statements before submitting them to the company's board of directors for approval. Finally, the chairman of the board certifies the annual report and then it is filed with the securities exchange to be published for public use. The figure also locates the three main parts of the proposed audit trinity report. 


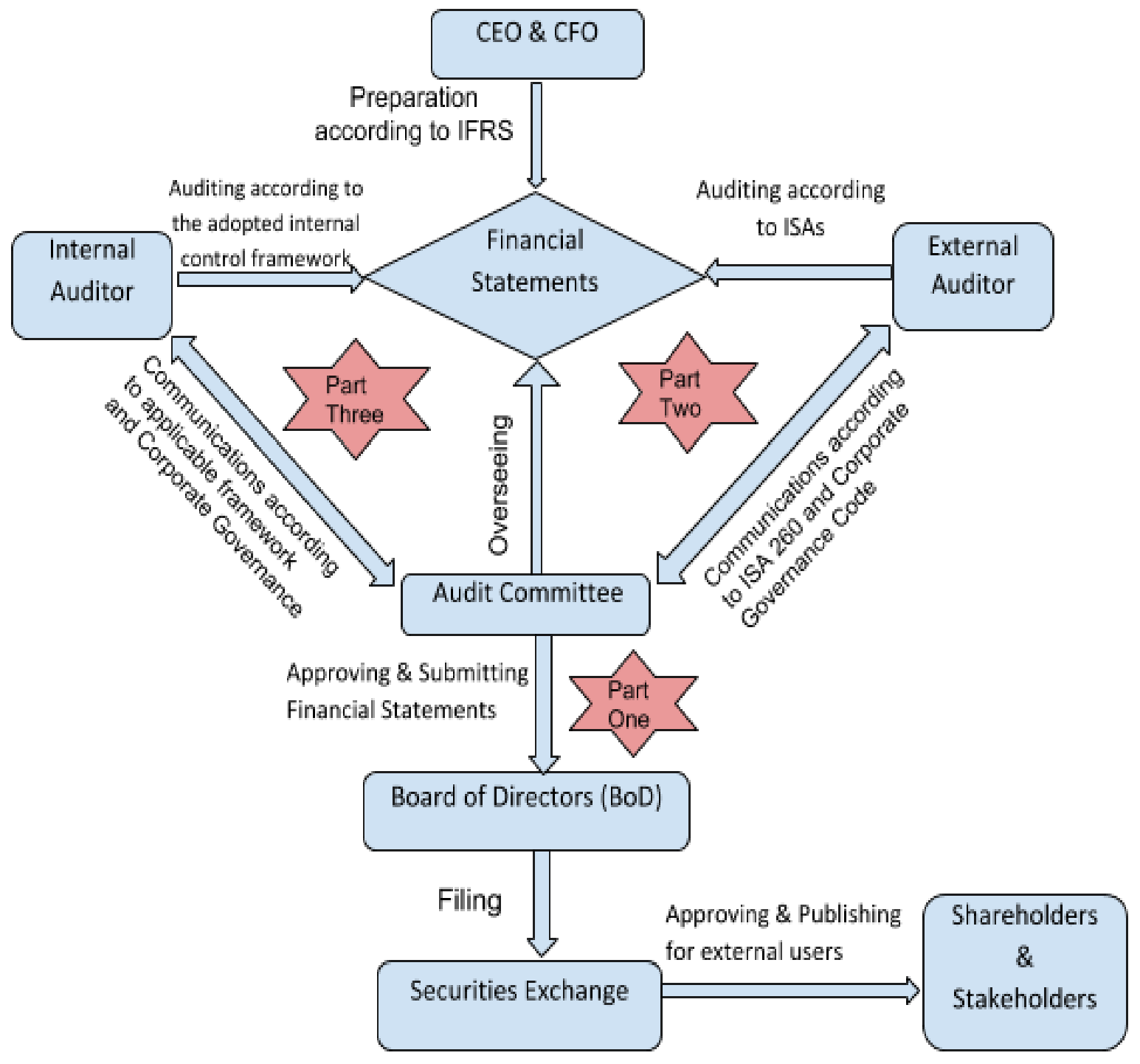

Figure 1. The Role of the Audit Trinity in Securing Financial Reporting Integrity

Figure one is developed by the researcher

\section{Relationship and Compatibility with Internationally Recognized Frameworks}

Perceived objectives of the proposed audit trinity report are consistent with the objectives of the International Standards on Auditing, internationally recognized internal control frameworks and global corporate governance best practices.

Regarding internal control over financial reporting, both The Committee of Sponsoring Organizations of the Treadway Commission (COSO) and The Institute of Internal Auditors (IIA) affirmed the vital role of the audit committee in securing the financial reporting system. The internal control- integrated framework of COSO stated that the primary function of the audit committee is to "oversee internal control over financial reporting and the integrity and transparency of external reporting, including financial reports" (COSO, 2013, p. 97). The framework of COSO required internal auditors to report and communicate key audit factors to the audit committee to limit the risk of management capture of the audit activity. Furthermore, the framework required a regular evaluation of the internal audit plan by the audit committee to ensure its effectiveness. In addition, the IIA's International Standards for the Professional Practice of Internal Auditing provides a framework and guidance for properly securing the internal audit functions. The standards defined internal audit independence as "the freedom from conditions that threaten the ability of the internal audit activity to carry out internal audit responsibilities in an unbiased manner". The IIA standard No. 
2060 - require internal auditors to report to executive management and the independent audit committee as a governance body of the board (IIA, 2017, p. 21). Examples of matters that need to be communicated by the head of the internal auditors: internal audit functions, plans, and how to maintain internal audit independence from other executives and activities. Moreover, internal auditors must report to the audit committee any dispute between them and the company management regarding audit risks.

International Standards on Auditing (ISAs) also considered the importance of communications between both external and internal auditors with those charged with governance. The ISA. 260 "provides an overarching framework for the auditor's communication with those charged with governance, and identifies some specific matters to be communicated with them" (ISA 260, p. 226). The ISA 260 stated that communication with the audit committees is a key element for corporate governance best practices. The standard also highlighted the importance of conducting regular meetings with the audit committee including at least one meeting without the presence of company management (ISA 260, para. A7). Examples of significant matters to be communicated according to the ISA 260 are: auditor's responsibilities in auditing financial statements, audit opinion, audit plan, scope, time of audit, the provision of non-audit services, auditor's judgment regarding accounting policies and estimates, disagreements with the company management, and discussing compliance with the requirements of auditor's independence. Similarly, the ISA No. 265 "deals with the auditor's responsibility to communicate appropriately to those charged with governance and management deficiencies in internal control that the auditor has identified in an audit of financial statements"(ISA 265, p. 256). This standard is a living example of the importance of the role of the audit committee as a liaison tool between external and internal auditors. Thus, the joint audit trinity report of this study aims to integrate their auditing tasks and coordinate their efforts to adequately secure financial reporting.

Internationally recognised frameworks and corporate governance best practices such as the U.S Sarbanes-Oxley Act (SOX), the U.K FRC, the Australian ASX, and the EU Company Law Directive have addressed the essential roles of the tripartite audit in securing the financial reporting system and in fighting corporate corruption. In the U.S.A, spectacular corporate failures such as Enron and WorldCom led to calls for an efficient corporate governance mechanism. As a result, the U.S Congress released the SOX act in 2002 to reform corporate governance and protect the rights of the shareholders (e.g. mandatory audit rotation, restriction of non-audit services, the establishment of the Public Company Accounting Oversight Board, and the provisions that emphasize the role of the audit committees in in reinforcing both internal and external auditor's independence and effectiveness). Moreover, the SOX has increased the burdens of the Chief Executive Officer and Chief Financial Officer that they will be personally responsible for publishing deficient financial statements.

In Europe, the UK Financial Reporting Council (FRC) established the UK Corporate Governance to ensure the soundness of corporate governance system and financial reports (UK Corporate Governance Code, 2016), Section "C" of the UK code discusses the role of the audit committee in three main principles that are: (1) the application of corporate reporting and risk management (2) the implementation of internal control principles, and (3) maintaining an effective relationship with the company's external auditors. Moreover, the UK FRC also set guidance on audit committees designed to assist audit committees in carrying out their tasks (Guidance on Audit Committees, 2016). The guidance requires audit committees to include a separate section in the annual report describing their work during the fiscal year.

\section{The Proposed Audit Trinity Report}

The audit trinity report consists of three Parts or paragraphs. Part one deals with meeting the requirements of forming an audit committee in accordance with the legislation in force and corporate governance instructions. Matters to be addressed in this section include audit committee formation, qualifications and experience of members, number and minutes of meetings, audit committee charter and the status of members based on definitions of independence/non-independence and executive/non-executive. It is worth mentioning that audit committee members, as well as all directors and executives, have to disclose their CVs within the annual report. This section is to be certified by both chairman of the board of directors and chairman of the audit committee. Part two deals with the role of the audit committee in all decisions related to ensuring external auditor's independence and performance. This section is to be signed by both chairman of the audit committee and the external auditor. Part three deals with the role of the audit committee in all decisions related to maintaining the internal auditor's effectiveness and independence from the company management. This section is to be signed by both chairman of the audit committee and chief internal auditor. 


\section{Part One: Audit Committee Formation and Responsibilities:}

The audit committee has been established and formed of [3] independent, non-executive, qualified and experienced members according to the [applicable laws and Instructions of corporate governance]. The audit committee discharges all of its responsibilities under a documented charter approved by the board of directors. Sufficient resources, facilities, and power needed to discharge its responsibility of monitoring the integrity of the financial statements have been adequately provided.

For this financial period, the audit committee reviewed financial statements regarding completeness, fairness, accuracy, and compliance with statutory requirements and any necessary recommendations were provided to the board for final approval before submitting to the Securities Exchange. The committees also declare that any related parties transactions and the provision of non-audit services have been reviewed and pre-approved to ensure there is no conflict of interest. The committee also monitors whistleblowing procedures to ensure necessary arrangements for confidential, communication with whistleblowers and for following up an independent investigation.

During this financial period, the committee has conducted [at least One meeting each quarter]. Audit committee $\mathrm{CVs}$, remunerations and summary of their activities and meetings are included in the annual reports.

\section{Chairperson of Audit Committee [signature] Chairperson of Board [signature]}

\section{Part Two: Communications with the External Auditor:}

External auditor nomination, tenure, remuneration, and dismissal decisions rest with the audit committee. The committee has conducted [at least three meetings a year] with the external auditor without the presence of the company executives. The first meeting agenda discussed approving the engagement letter, the sufficiency of audit scope and plan, and external auditor's independence according to the [International Ethics Standards Board for Accountants' Code of Ethics for Professional Accountants (IESBA Code), and applicable laws and regulations]. Subsequent meetings discussed reviewing external auditor's evaluation of the internal audit function, the appropriateness of accounting policies, judgements, estimates, and auditor assessments of entity's ability to continue as a going concern and follow up management responses to auditor observations, suggestions and key audit matters. The committee also, continually, inquires of the auditor about any management interference or pressure that may jeopardize their independence.

During the engagement period, the amount of total fees due/paid [\$], consists of $[\$]$ audit services and $[\$]$ non-audit services. The following table summarises a description of the nonaudit services [If any] which had been previously approved by the audit committee.

\begin{tabular}{|c|c|c|c|}
\hline No. & Description of Nonaudit services provided & Amount & $\begin{array}{l}\text { Percentage } \\
\text { to total fees }\end{array}$ \\
\hline & & & \\
\hline Total & & \\
\hline
\end{tabular}

\section{Engagement Partner [signature] Chairperson of Audit Committee [signature]}

\section{Part Three: Internal Audit Function \& Internal Control:}

The audit committee appointed the head of the internal audit based on the criteria set by the Nomination and Remuneration Committee of the board of directors. Decisions related to the head of internal audit dismissal and remuneration also rest with the audit committee to maintain internal auditor's independence from the company management and other activities.

The audit committee provides internal auditors with a direct reporting line to adequately respond to their reports and findings promptly, especially for those relating to any breaches, manipulative act, and misuse of credit that appear as a result of their work. The committee has conducted [at least two meetings a year] with the internal auditors without the presence of any of the company executives.

The committee reviews the robustness of risk management and internal control systems regularly. Based on internal 
control evaluation by the audit committee and the external auditor, the audit committee communicates any potential deficiencies and suggests improvements to the board of directors to ensure effective internal control in the company.

Chief Internal Audit [signature]

Chairperson of Audit Committee [signature]

\section{Conclusion}

Poor corporate governance, weak audit committees and a lack of accountability allowed unexpected corporate failures such as the collapse of Enron and the demise of their external auditor Arthur Andersen in 2001 (Bajra \& Cadez, 2018). The U.S. SOX and other similar laws worldwide were ostensibly aimed at enhancing corporate accountability by giving more power to audit committees. Notwithstanding, the world witnessed the Global Financial Crisis (GFC) in 2008 resulting in other corporate collapses triggered by the failure of Lehman Brothers bank without warnings by auditors. The GFC, together with frequent worldwide corporate-audit firm scandals warn us that there is an imbalance in the current corporate governance systems, regulatory legislation, and annual report structure and dissemination. Thus, it is necessary to reform that imbalance. In line with the objectives of the international standards on auditing, internationally recognized internal control frameworks and global corporate governance best practices, the proposed audit trinity report of this study integrates and coordinates efforts of the tripartite audit in securing financial statements' credibility and corporate governance pillars. The joint report also adds more responsibilities amongst corporate governance constituents in that by signing directors/auditors certify they have adequately complied with applicable regulations and corporate governance framework and that auditors have followed accounting and auditing standards, and have been adequately monitored by the audit committee and the board of directors. Thus, the joint effort of the audit trinity helps in mitigating conflicts of interest by implementing a rigorous control over the quality of financial reporting.

\section{Practical Implications}

Practically, perceived benefits of the proposed audit trinity report could be as follows:

1- Adopting the proposed audit trinity report encourages related regulating bodies (e.g. Securities Exchange Commission, Association of CPAs, and Association of Internal Auditors) to work integrally on balanced regulations and a corporate governance code.

2- The proposed audit trinity report suggests additional improvements to the corporate governance structure and the annual report by adding a special report signed and certified by the chairman of the board, the chairman of the audit committee, the engagement partner and chief internal auditor. This certification confirms their responsibilities and that they have, integrally and jointly, performed their interrelated professional duties.

3- The tripartite audit (audit committee, external auditor, and internal auditor) involved in securing financial reporting system can learn from the suggested report of this study that they should share and confront their views to better coordinate their auditing and quality control efforts.

4- Enhancing the quality of disclosure and transparency of the annual report by disclosing details of non-audit services in comparison to total audit fees especially in developing countries whose laws do not require such disclosure.

5- External auditors may refer to their contribution and certification of the audit trinity report under the last paragraph of the audit report, because the last paragraph of the revised International Standard on Auditing No. 700 deals with auditors' responsibility on reporting about local laws and other regulatory requirements.

\section{Limitations \& Future Studies}

This study has two limitations: Firstly, the proposed report of this study discusses the joint roles of audit committees with both external and internal auditors in securing the integrity of financial reporting, this means that the role of audit committees in monitoring financial statements' preparation (by the company executives) hasn't been considered in the proposed audit trinity report. Secondly, many companies whether in developed or developing countries do not have an internal audit function, especially for small listed companies. This means that the third paragraph of the proposed report will be considerably affected. However, the researcher suggests solving this issue as recommended by the UK Guidance on Audit Committees which states

Where there is no internal audit function, the audit committee should consider annually whether there is a need for an internal audit function and make a recommendation to the board, and the reasons for the 
absence of such a function should be explained in the relevant section of the annual report (Guidance on Audit Committees, 2016, section C.3.6).

Regarding suggested future studies, as with theoretical and literature review studies, this study could be further enhanced and backed by empirically investigating the perceptions of the tripartite audit, company directors and executives, in addition to surveying the attitudes of related associations and government regulating bodies. Feedback obtained from those parties will be essential data for future studies aiming at finding a balanced, practical implementation of the proposed audit trinity report. Another suggested future research could be stemmed from the above limitation which is considering the importance and the contribution of adding a fourth paragraph to deal with the audit committee's responsibility in overseeing company management activities, especially in the preparation of the financial statements and in maintaining corporate accountability over the company executives. Finally, adopting the proposed report of this study require some amendments to corporate governance structure, future studies are needed to consider updating corporate governance codes.

\section{References}

Al-Baidhani,. A. (2014). The Role of Audit Committee in Corporate Governance: Descriptive Study, International journal of research \& methodology in social science, 2(2), 45-57. http://dx.doi.org/10.2139/ssrn.2487167

Al-Hajri, M, O,. (2018). The Impact Of The Joint Provision Of Non-Audit Services On Audit Firm Tenure: A Kuwaiti Evidence, The Journal of Applied Business Research, 34(1), 69-80. https://doi.org/10.19030/jabr.v34i1.10093

Alqatamin, R. M. (2018). Audit Committee Effectiveness and Company Performance: Evidence from Jordan, Accounting and Finance Research, 7(2), 48-60. https://doi.org/10.5430/afr.v7n2p48

Al-Sawalqa, F. (2013). Transparency of Annual Corporate Reports' Contents in Jordan: Is it questionable?, International Journal of Academic Research in Accounting, Finance and Management Sciences, 3(1), 409-417. Retrieved September 10, 2018 from: http://hrmars.com/admin/pics/1710.pdf

Arens, A., Elder, R., Beasley, M., \& Hogan, C. (2017). Auditing and Assurance Services, Global Edition, 16/E.

Bajra, U., \& Cadez, S. (2018). Audit committees and financial reporting quality: The 8th EU Company Law Directive perspective. Economic Systems, 42(1), 151-163. https://doi.org/10.1016/j.ecosys.2017.03.002

Beck, M. J., \& Mauldin, E. G. (2014). Who's Really in Charge? Audit Committee versus CFO Power and Audit Fees. Accounting Review, 89(6), 2057-2085. https://doi.org/10.2308/accr-50834

Boţa-Avram C. (2011). Some arguments that justify the audit's trinity's approach in the context of corporate governance, Studies in Business and Economics, 6(1), 5-18. Retrieved August 5, 2018 from: http://eccsf.ulbsibiu.ro/RePEc/blg/journl/611Bota-Avram.pdf

Bratton, W. (2003). Shareholder Value and Auditor Independence. Duke Law Journal, 53(2), 439-489. Retrieved from http://www.jstor.org/stable/1373143

Choi, Y. K., Han, S. H., \& Lee, S. (2014). Audit committees, corporate governance, and shareholder wealth: Evidence from Korea. Journal of Accounting and Public Policy, 33(5), 470-489. https://doi.org/10.1016/j.jaccpubpol.2014.06.001

Christopher, J., Sarens, G., \& Leung, P. (2009). A critical analysis of the independence of the internal audit function: Evidence from Australia. Accounting, Auditing and Accountability Journal, 22(2), 200-220. https://doi.org/10.1108/09513570910933942

Cooper B.J., \& Grose, R. (2010). Trust Me: I'm An Auditor. International Review of Business Research Papers 6(5), $160-166$.

COSO. (2013). The Committee of Sponsoring Organizations of the Treadway Commission- The internal control integrated framework. Available at: https://www.coso.org/Pages/default.aspx

Craswell, A., Stokes, D. J., \& Laughton, J. (2002). Auditor independence and fee dependence. Journal of Accounting and Economics, 33(2), 253-275. https://doi.org/10.1016/S0165-4101(02)00044-7

Dibra, R. (2016). Corporate Governance Failure: The Case Of Enron And Parmalat. European Scientific Journal, 12(16), 283-290. https://doi.org/10.19044/esj.2016.v12n16p283

Endaya, K. A., \& Hanefah, M. M. (2016). Internal auditor characteristics, internal audit effectiveness, and moderating effect of senior management. Journal of Economic and Administrative Sciences, 32(2), 160-176. https://doi.org/10.1108/JEAS-07-2015-0023 
Fan, J. \& Wong, T. (2005). Do External Auditors Perform a Corporate Governance Role in Emerging Markets? Evidence from East Asia. Journal of Accounting Research, 43(1), 35-72. https://doi.org/10.1111/j.1475-679x.2004.00162.x

Gavious, I. (2007). Alternative perspectives to deal with auditors' agency problem. Critical Perspectives on Accounting, 18(4), 451-467. https://doi.org/10.1016/j.cpa.2006.01.011

Guidance on Audit Committee. (2016). Guidance on Audit Committee, issued by The UK Financial Reporting Council, available at: https://www.frc.org.uk/getattachment/b34eb292-f875-4d00-b46c-665b8d88b12b/Guidance-on-Audit-Committe es-FINAL-DRAFT.pdf

IIA. (2017). The Institute of Internal Auditors. International Standards for the Professional Practice of Internal Auditing. $\quad$ Retrieved July 11, 2018, from: https://na.theiia.org/standards-guidance/Public\%20Documents/IPPF-Standards-2017.pdf

ISA 260. (2016). Auditor's communication with those charged with governance, International Standards on Auditing ISA 260 issued by the IAASB of the IFAC, accessed on June 2018, available at: https://www.ifac.org/about-ifac/publications-resources

ISA 265. (2016). Communicating Deficiencies in Internal Control to Those Charged with Governance and Management, International Standards on Auditing ISA 265, issued by the IAASB of the IFAC, accessed on June 2018, available at: https://www.ifac.org/about-ifac/publications-resources

Janvrin, D. (2008). To what extent does internal control effectiveness increase the value of internal evidence? Managerial Auditing Journal, 23(3), 262-282. https://doi.org/10.1108/02686900810857712

Jensen, M. C., \& Meckling, W. H. (1976). Theory of the firm: Managerial behavior, agency costs and ownership structure. Journal of Financial Economics, 3(4), 305-360. https://doi.org/10.1016/0304-405X(76)90026-X

Jr, B. D. (2018). Audit firm KPMG suspended in Oman over "irregularities." Retrieved November 20, 2018, from https://www.arabianbusiness.com/banking-finance/408185-audit-firm-kpmg-suspended-in-oman-over-irregulari ties

Krishnan, J., Sami, H., \& Zhang, Y. (2005). Does the Provision of Nonaudit Services Affect Investor Perceptions of Auditor Independence? Auditing: A Journal of Practice \& Theory, 34(2), 111-135. https://doi.org/10.2308/aud.2005.24.2.111

Law, P., (2008). An empirical comparison of non-Big 4 and Big 4 auditors' perceptions of auditor independence", Managerial Auditing Journal, 23(9), 917-934. https://doi.org/10.1108/02686900810908454

Mak, T., Cooper, K., Deo, H., \& Funnell, W. (2005). Audit, accountability and an auditor's ethical dilemma: A case study of HIH Insurance. Asian Review of Accounting, 13(2), 18-35. https://doi.org/10.1108/eb060785

McMillan, K. P. (2004). Trust and the virtues: a solution to the accounting scandals? Critical Perspectives on Accounting, 15(6), 943-953. https://doi.org/10.1016/j.cpa.2002.11.001

Nawawi, A., \& Salin, A. S. A. P. (2018). Employee fraud and misconduct: empirical evidence from a telecommunication company. Information and Computer Security, 26(1), 129-144. https://doi.org/10.1108/ICS-07-2017-0046

Nixon, A. (2004). Special reports: FTSE 100 auditors survey—big four defend non-audit earnings. Accountancy Magazine, 2004, September issue, page 34. Retrieved March 15, 2018 from https://library.croneri.co.uk/accmag_0409_041

Park, B. (2018). Audit Committees and Managerial Influence on Audit Quality: 'Voluntary' versus 'Mandatory' Approach to Corporate Governance. Australian Accounting Review. https://doi.org/10.1111/auar.12263

PCAOB. (2017). PCAOB Announces $\$ 1.5$ Million Settlement with Grant Thornton for Quality Control Violations and Audit Failures. Retrieved July 23, 2018, from https://pcaobus.org:443/News/Releases/Pages/PCAOB-Announces-\$1-5-Million-Settlement-with-Grant-Thornt on-for-Quality-Control-Violations-and-Audit-Failures-.aspx

PCAOB. (2018a). PCAOB Censures and Fines Deloitte \$500,000 for Material Accounting Errors It Missed in 3 Consecutive Audits of Jack Henry. Retrieved July 23, 2018, from https://pcaobus.org:443/News/Releases/Pages/PCAOB-Censures-Fines-Deloitte-\$500,000-for-Jack-Henry-Audi ts.aspx 
PCAOB. (2018b). PCAOB sanctions former Deloitte Turkey CEOs over altered documents. (2018, May 11). $\begin{array}{llll}\text { Retrieved July } & 23, & 2018, & \text { from }\end{array}$ https://www.accountancyage.com/2018/05/11/pcaob-sanctions-former-deloitte-turkey-ceos-over-altered-docume nts/

Porter, B. (2008). The Role of the Tripartite Audit Function in Securing Corporate Accountability (September 25, 2008). Working Paper No. 64. Retrieved May 13, 2018, from: https://ssrn.com/abstract=2046347 or http://dx.doi.org/10.2139/ssrn.2046347

Porter, B. (2009). The audit trinity: the key to securing corporate accountability", Managerial Auditing Journal, 24( 2), 156-182. https://doi.org/10.1108/02686900910924563

Prawitt, D., Smith, J. \& Wood, D. (2009). Internal audit quality and earnings management. The Accounting Review, 84(4), 1255-1280. https://doi.org/10.2308/accr.2009.84.4.1255

Oussii, A. A., \& Boulila Taktak, N. (2018). The impact of internal audit function characteristics on internal control quality. Managerial Auditing Journal, 33(5), 450-469. https://doi.org/10.1108/MAJ-06-2017-1579

Rezaee, Z. (2005). Causes, consequences, and deterrence of financial statement fraud, Critical Perspectives on Accounting, 16(3), 277-298. https://doi.org/10.1016/S1045-2354(03)00072-8

Roussy, M, \& Brivot, M. (2016). Internal audit quality: a polysemous notion?. Accounting, Auditing \& Accountability Journal, 29(5), 714-738. https://doi.org/10.1108/AAAJ-10-2014-1843

Sharma, D. S., \& Sidhu, J. (2001). Professionalism vs Commercialism: The Association Between Non-Audit Services (NAS) and Audit Independence. Journal of Business Finance, Accounting, 28(5-6), 563-594. https://doi.org/10.1111/1468-5957.00386

Schneider, A., Church, B. K., \& Ely, K. M. (2006). Non-Audit Services and Auditor Independence: A Review of the Literature. Journal of Accounting Literature, 25, 169-211. Retrieved June 10, 2018 from https://search.proquest.com/openview/0d45a63bb18ba412d773cee271b0ed33/1?pq-origsite=gscholar\&cbl=313 66

Shbeilat, M. (2014). A proposed model of audit committee to reinforce corporate governance system in Jordan. Journal of Emerging Trends in Economics and Management Sciences, 5(5), 507-514. Retrieved June 18, 2018 from http://jetems.scholarlinkresearch.com/abstractview.php?id=0.21

Shbeilat, M. \& Harasis N. (2018). Do listed companies Need an IFRS Committee Beside Audit Committee?, International Journal of Academic Research in Accounting, Finance and Management Sciences, 8(2), 8-18, https://doi.org/10.6007/IJARAFMS/v8-i2/4075

Stewart, J. \& Subramaniam, N. (2010). Internal audit independence and objectivity: emerging research opportunities, Managerial Auditing Journal, 25(4), 328-360. https://doi.org/10.1108/02686901011034162

Sweet, P. (2018). FRC auditor fines hit $£ 18 \mathrm{~m}$ mark | Accountancy Daily. Retrieved July 31, 2018, from https://www.accountancydaily.co/frc-auditor-fines-hit-ps18m-mark

Tillema, S., \& ter Bogt, H. J. (2016). Does an Agency-Type of Audit Model Fit a Stewardship Context? Evidence from Performance Auditing in Dutch Municipalities. Financial Accountability \& Management, 32(2), 135-156. https://doi.org/10.1111/faam.12084

UK Corporate Governance Code. (2016). The UK Corporate Governance Code, issued by The UK Financial Reporting Council, available at: https://www.frc.org.uk/getattachment/ca7e94c4-b9a9-49e2-a824-ad76a322873c/UK-Corporate-Governance-Co de-April-2016.pdf

Wang, S., \& Hay, D. (2013). AUDITOR INDEPENDENCE IN NEW ZEALAND: FURTHER EVIDENCE ON THE ROLE OF NON-AUDIT SERVICES. Accounting and Management Information Systems, 12(2), 235-262. http://hdl.handle.net/2292/21851

Watts, R., \& Zimmerman, J. (1983). Agency Problems, Auditing, and the Theory of the Firm: Some Evidence. The Journal of Law \& Economics, 26(3), 613-633. https://doi.org/10.1086/467051

Yeoh, P. (2015). Corporate governance failures and the road to crime. Journal of Financial Crime, 23(1), 216-230. https://doi.org/10.1108/JFC-10-2014-0044

Zhang, Y. (Elli), Hay, D., \& Holm, C. (2016). Non-audit services and auditor independence: Norwegian evidence. Cogent Business \& Management, 3(1), 1-41. https://doi.org/10.1080/23311975.2016.1215223 